\title{
Hubungan Persepsi Keterlibatan Ayah dalam Pengasuhan dan Kesiapan Menikah Emerging Adult Perempuan di Surabaya
}

\author{
ESTER FELICIANA \& DUTA NURDIBYANANDARU* \\ Departemen Psikologi Pendidikan dan Perkembangan, Fakultas Psikologi Universitas Airlangga
}

\begin{abstract}
ABSTRAK
Penelitian ini bertujuan untuk mengetahui hubungan antara persepsi keterlibatan ayah dalam pengasuhan dan kesiapan menikah emerging adult perempuan di Surabaya. Penelitian dilakukan secara online pada 128 responden perempuan dengan rentang usia 18-25 tahun. Alat ukur yang digunakan adalah kuisioner persepsi keterlibatan ayah dalam pengasuhan yang disusun berdasarkan teori Pleck (2010) dan kuisioner kesiapan menikah yang berdasarkan teori Blood (1978), beserta satu aitem pendukung penelitian dengan total keseluruhan 88 aitem. Kedua alat ukur tersebut disusun secara mandiri melalui uji coba terpakai. Reliabilitas kesiapan menikah menunjukkan nilai 0,776 dan persepsi keterlibatan ayah dalam pengasuhan menunjukkan nilai 0,995, artinya, kedua alat ukur yang digunakan memiliki reliabilitas yang tinggi. Analisis data dilakukan dengan Pearson Product Moment Correlation, dengan menggunakan IBM SPSS Statistic 22. Hasil penelitian yang sudah dilakukan menunjukkan bahwa terdapat hubungan antara persepsi keterlibatan ayah dalam pengasuhan dengan kesiapan menikah yang signifikan pada emerging adult perempuan di Surabaya. Hasil penelitian ini dapat digunakan sebagai referensi untuk dunia psikologi pendidikan dan perkembangan terkait dengan topik kesiapan menikah.
\end{abstract}

Kata kunci: emerging adult perempuan, kesiapan menikah, persepsi keterlibatan ayah dalam pengasuhan

\begin{abstract}
This study aimed to determine the relationship between Perceived Father Involvement and Readiness for Marriage in Emerging Adult Female in Surabaya. There were 128 female respondents between 1825 years old, and the data were collected online. The instruments used were Perceived Father Involvement Questionnaire based on Pleck's theory (2010), Readiness for Marriage based on Blood's theory (1978), and one supporting item totaling 88 items. The measuring instruments were arranged independently through a preliminary study. The Readiness of Marriage's reliability value was 0.0776, and the Perceived Father Involvement value was 0.995, confirming that the two measuring instruments have high reliability. The data were analyzed using Pearson Product Moment Correlation on IBM Statistics 22. The significant value was 0.007 . Thus, there was a significant correlation between readiness for marriage and perceived father involvement in emerging adult females in Surabaya. The research result can be used as a reference for educational and developmental psychology, particularly related to readiness for marriage.
\end{abstract}

Keywords: female emerging adult, perceived father involvement, readiness for marriage 
INSAN Jurnal Psikologi dan Kesehatan Mental, 2019, Vol. 4(1), 28-35, doi: 10.20473/jpkm.v4i12019.28-35 Dikirimkan: 16 Oktober 2019 Diterima: 10 Desember 2019 Diterbitkan: 27 Februari 2020 Editor: Atika Dian Ariana

*Alamat korespondensi: Fakultas Psikologi Universitas Airlangga, Jalan Airlangga 4-6 Surabaya 60286. Pos-el: duta.nurdibyanandaru@psikologi.unair.ac.id

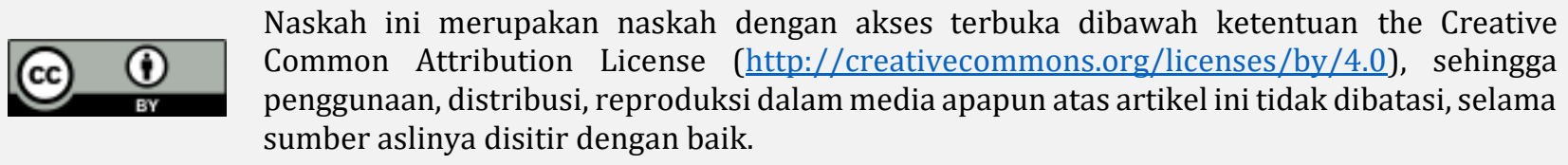

\section{P E N D A H U L U A N}

Transisi peran yang menjadi penanda seseorang sudah mencapai kedewasaan pada masyarakat barat antara lain: dapat menggunakan hak suara dalam pemilihan umum, menyelesaikan pendidikan, memiliki pekerjaan penuh waktu, tinggal terpisah dari orangtua, menikah, dan menjadi orangtua (Arnett, 2004). Memilih pasangan, belajar hidup bersama suami atau istri, dan memulai keluarga merupakan sebagian dari tugas perkembangan dewasa awal (Ralston \& Thomas, 2012). Hal tersebut sejalan dengan pendapat Arnett $(2006,2007)$ yang menyatakan bahwa pada masa emerging adult merupakan peralihan dari masa remaja menuju kedewasaan, sebuah masa penentuan jenjang karir yang akan ditempuh, bagaimana identitasnya akan dibentuk, dan gaya hidup mana yang akan dijalani (misalnya lajang, hidup bersama, atau menikah) (Santrock, 2010). Konsep perkembangan yang baru ini berfokus pada usia 18 sampai 25 tahun (Arnett, 2000). Erikson (1968) dan Eindfuss (1991) mengemukakan bahwa bagi banyak orang, masa perkembangan ini merupakan masa dimana perubahan sering terjadi karena berbagai kemungkinan dalam hal percintaan, pekerjaan, dan pandangan hidup semakin tereksplorasi (Arnett, 2000).

Masyarakat Indonesia mencapai status dewasa sepenuhnya melalui pernikahan dan menjadi orangtua. Menurut Thornton dan Young-DeMarco (2001), emerging adult adalah masa perkembangan yang tepat untuk mengkaji kesiapan menikah karena mayoritas emerging adult sedang merencanakan dan mengharapkan pernikahan (Badger, 2005). Pernikahan merupakan suatu institusi sosial dimana dua orang berkomitmen untuk menjalani hubungan yang diakui secara sosial, dimana hubungan seksual adalah hal yang sah dan ada tanggung jawab hukum dalam hal keturunan serta pasangan. Ketika individu menikah, ia akan memainkan peran baru, baik sebagai suami, maupun sebagai istri. Oleh karenanya, dalam memasuki pernikahan memerlukan kesiapan tertentu (Rumondor, 2015). Dalam kajian psikologi, kesiapan berarti suatu derajat seseorang siap untuk bertindak atau merespon stimulus tertentu (Nugent, 2013). Ditinjau dari asal kata, maka kesiapan menikah atau marriage readiness bisa diartikan sebagai keadaan siap berespon pada komitmen dan tanggung jawab dalam pernikahan (Rumondor, 2015).

Ketika kita berbicara mengenai pernikahan dan usia, gender memiliki peran di dalamnya. Laki-laki seringkali disarankan untuk menunda pernikahan hingga mereka merasa siap, yang artinya mereka dewasa, finansial stabil, membangun karir, dan merasa nyaman dengan dirinya sendiri. Hal ini memberi kesempatan kepada laki-laki untuk memperpanjang masa remajanya dan waktu lebih untuk mencari orang yang tepat. Penelitian Blakemore (2005) menemukan bahwa perempuan memiliki dorongan untuk menikah yang lebih tinggi daripada laki-laki dan perempuan yang memiliki dorongan menikah yang tinggi cenderung kurang berfokus pada karirnya.

Studi Badger (2005) yang meneliti persepsi kesiapan menikah di emerging adult menemukan bahwa sebanyak 67\% subjek perempuan merasa tidak siap menikah dan hanya sebanyak $5 \%$ perempuan yang

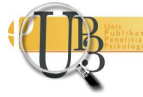


merasa sudah siap menikah. Sementara pada subjek laki-laki sebanyak $60 \%$ merasa tidak siap menikah, dan sebanyak 9\% merasa sudah siap menikah. Artinya, dengan tingginya angka perempuan yang tidak siap untuk menikah, sementara dorongan untuk menikah lebih tinggi daripada laki-laki, perempuan menjadi subjek yang potensial untuk studi kesiapan menikah.

Studi Badger (2005) menemukan usia ideal untuk menikah menurut emerging adult: (1) Laki-laki 25,1 tahun; (2) Perempuan 25,0 tahun. Meskipun demikian, Badger (2005) mengemukakan bahwa secara konsep emerging adulhood, trend di usia ini cenderung 'menunda' menikah. Sebab menurut Badger (2005), untuk melihat kesiapan menikah, harus melihat bagaimana personal readiness, perasaan, dan sikap-sikap dari masing-masing individu untuk memutuskan menikah.

Penundaan ini dapat dilihat dari data Badan Pusat Statistik (2010), yang menyatakan bahwa sebanyak 81.613 orang perempuan dan 15.218 laki-laki usia 25-44 tahun di perkotaan yang belum menikah. Sedangkan di pedesaan didapatkan angka 15.314 orang perempuan dan 4.160 laki-laki. Artinya, estimasi angka penduduk berusia 25-44 tahun yang belum menikah didapati lebih banyak ada pada perempuan di daerah perkotaan. Menurut Badan Pusat Statistika (2010) terdapat 19,2\% atau 194.646 orang penduduk usia 25-44 tahun yang belum kawin di Surabaya yang merupakan kota terbesar kedua di Indonesia (Dickson, 2015).

Menurut Whitehead \& Popenoe (2000), emerging adult mendapatkan ide dan model pernikahan dari orangtua dan generasi sebelumnya. Kemudian, penelitian Axinn dan Thornton (1992) dan Heaton (2002) membuktikan bahwa sikap orangtua, perilaku, dan nilai yang dianut secara signifikan memberi dampak pada sikap dan kepercayaan emerging adult tentang pernikahan. Pada hubungan pengasuhan orangtua yang positif, anak melihat model dari bagaimana dua orang berelasi, bekerjasama, bernegosiasi, dan berkompromi. Anak yang belajar kemampuan ini cenderung untuk lebih mudah akrab dengan teman sebaya dan pasangannya nanti (Badger, 2005).

Mengenai hubungan dengan keluarga, pola pengasuhan antara ayah terlibat pada pengasuhan instrumental seperti sebagai penasihat (Youniss, 1985 dalam Princeton University, 2008). Menurut Shapiro (2013), keterlibatan ayah mampu mendukung dan menstimulasi rasa ingin tahu, minat menjelajah, dan kemampuan anak-anak perempuan untuk bertindak mandiri. Selain itu, peran ayah juga penting untuk meningkatkan kemampuan anak perempuan dalam menjalankan hubungan dengan sosok pria dan kemampuan mereka untuk menjalin hubungan sebagai orang dewasa (Abdullah, 2009). Artinya, keterlibatan ayah dalam pengasuhan menjadi penting untuk emerging adult perempuan karena mereka akan mengeksplorasi dan membuat keputusan mengenai arah kehidupan (Princeton University, 2008)

Keterlibatan ayah berkaitan dengan keterlibatan positif antara ayah dengan anak (Pleck, 1997 dalam Hodgins, 2007) yang bervariasi sepanjang waktu dalam rentang perkembangan dan berkorelasi dengan komponen sosial ekologi dan keadaan hidup anak (Palkovitz, 1997 dalam Hodgins, 2007). Menurut Pleck (2010) Persepsi Keterlibatan Ayah dalam Pengasuhan memiliki 5 dimensi, yaitu: (a) positive engagement; (b) warmth and responsiveness; (c) control; (d) indirect care; dan (e) process responsibility.

Hipotesis

$\mathrm{H}_{0} \quad$ : Tidak ada hubungan antara persepsi terhadap keterlibatan ayah dengan kesiapan menikah emerging adult perempuan di Surabaya

$\mathrm{H}_{\mathrm{a}} \quad$ : Ada hubungan antara persepsi terhadap keterlibatan ayah dengan kesiapan menikah emerging adult perempuan di Surabaya 


\section{MET ODE}

Tipe Penelitian pada penelitian yang dilakukan penulis yaitu tipe penelitian kuantitatif dengan menggunakan metode survei. Subjek penelitian ini adalah emerging adult perempuan di Surabaya dengan kriteria subjek yaitu; (1) Berusia 18-25 tahun; (2) Belum menikah; (3) Memiliki pacar; (4) Memiliki figur ayah; (5) Perempuan yang berdomisili di Surabaya. Penulis menggunakan Non Probability Sampling dengan teknik Purposive Sampling. Penelitian ini menggunakan teknik pengumpulan data dengan teknik survei. Teknik survei yang diberikan pada responden berupa kuesioner.

Kuisioner yang digunakan dalam penelitian merupakan alat ukur yang dikembangan secara mandiri oleh penulis. Alat ukur kesiapan menikah (Readiness for Marriage Questionnaire - RMQ) disusun berdasarkan teori kesiapan menikah Blood (1978). Pernyataan-pernyataan dalam alat ukur tersebut disampaikan kepada rater untuk memastikan bahwa pernyataan yang terkandung dalam alat ukur tersebut sudah sesuai dengan konsep yang ada pada teori. Alat ukur RMQ berjumlah 43 pernyataan dan menggunakan skala Likert dengan opsi enam pilihan jawaban yang mengukur respon subjek akan kesiapan menikahnya. Uji coba alat ukur penelitian ini dilakukan dengan 32 orang subjek. Hasil uji reliabilitas menunjukkan RMQ memiliki nilai 0,776. Semakin mendekati angka 1 (satu) nilai Cronbach's Alpha, maka semakin tinggi reliabilitasnya (Azwar, 2012), sehingga dapat dikatakan bahwa alat ukur yang akan digunakan memiliki reliabilitas yang tinggi. Sedangkan untuk alat ukur Persepsi Keterlibatan Ayah dalam Pengasuhan (perceived father involvement questionnaire - PFIQ) disusun secara mandiri oleh penulis berdasarkan teori Pleck (2010) dengan total 44 pernyataan yang menggunakan enam opsi pilihan jawaban. Alat ukur ini melalui proses rater dan uji reliabilitas, hasilnya didapatkan nilai 0,950.

\section{H A S I L P E N EL I T I A N}

Berdasarkan analisis statistik deskriptif variabel $\mathrm{x}$ dan y, dapat diketahui bahwa jumlah data yang diolah dalam penelitian ini sebanyak 128 subjek perempuan. Dari pengolahan data tersebut, Persepsi Keterlibatan Ayah dalam Pengasuhan memiliki rata-rata 186,28, nilai minimum sebesar 66, dan nilai maksimum sebesar 259. Kesiapan Menikah memiliki nilai rata-rata 208,80, nilai minimum sebesar 163, dan nilai maksimum sebesar 244 .

Penulis memastikan syarat-syarat yang harus dipenuhi untuk dapat melakukan uji korelasi lebih lanjut berikut adalah analisis terkait normalitas data. Uji nomalitas dilakukan untuk memenuhi syarat uji korelasi. Data berdistribusi normal apabila signifikansi memiliki nilai di atas 0,005. Dapat dilihat pada tabel, signifikansi Persepsi Keterlibatan Ayah dalam Pengasuhan memiliki nilai 0,200 dan Kesiapan Menikah bernilai 0,078, yang berarti data berdistribusi normal.

Analisis korelasi menunjukkan korelasi setiap dimensi X dengan variabel Y. Variabel Persepsi Keterlibatan Ayah dalam Pengasuhan memiiki nilai signifikansi kurang dari 0,05 dengan Persepsi Kesiapan Menikah. Hal ini menunjukkan bahwa terjadi hubungan antara kedua variabel tersebut. Nilai koefisien 0,238 berarti kekuatan hubungan termasuk lemah. Arah hubungan menunjukkan arah positif (+) sehingga bisa diartikan semakin tinggi $\mathrm{X}$ maka semakin tinggi $\mathrm{Y}$.

\section{I S K U S I}

Penelitian ini bertujuan untuk mengetahui hubungan antara persepsi keterlibatan ayah dalam pengasuhan dengan kesiapan menikah emerging adult di Surabaya secara empiris. Hasil dari analisis korelasi Pearson membuktikan bahwa hipotesis alternatif diterima, yaitu ada hubungan antara persepsi keterlibatan ayah dalam pengasuhan dengan kesiapan menikah emerging adult perempuan di Surabaya.

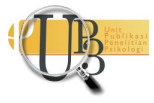


Pengujian data pada penelitian ini telah memenuhi syarat uji asumsi normalitas dan linearitas. Uji normalitas pada dimensi kesiapan menikah dan persepsi keterlibatan ayah dalam pengasuhan menunjukkan bahwa distribusi data bersifat normal. Data yang normal menunjukkan bahwa hasil penelitian pada variabel ini dapat digeneralisasikan kepada populasi. Berdasarkan hasil uji korelasi, kekuatan nilai korelasi yang didapatkan termasuk lemah. Dari nilai uji linearitas didapatkan hasil variabel $\mathrm{X}$ dan $\mathrm{Y}$ memiliki linearitas dan sifatnya positif, artinya, semakin tinggi nilai persepsi keterlibatan ayah dalam pengasuhan, semakin tinggi pula nilai kesiapan menikah. begitu pula sebaliknya, apabila persepsi keterlibatan ayah dalam pengasuhan menurun, maka kesiapan menikah juga akan menurun.

Penelitian ini membuktikan bahwa persepsi keterlibatan ayah dalam pengasuhan memiliki hubungan positif dengan persepsi kesiapan menikah emerging adult di Surabaya. Menurut Youniss (1985) ayah terlibat pada pengasuhan instrumental seperti sebagai penasihat (Princeton University, 2008) sehingga keterlibatan ayah dalam pengasuhan menjadi penting untuk emerging adult karena mereka akan membuat keputusan mengenai pilihan hidupnya. Karakteristik ayah sepertinya menjadi penyebab yang mempengaruhi banyaknya variasi dalam pendidikan anak, self-esteem, dan berkurangnya tekanan psikologi daripada karakteristik ibu (Brooks, 2010). Larson (1988) mengemukakan bahwa peran ini diperlukan untuk emerging adult untuk mempersiapkan diri menuju jenjang pernikahan karena dalam kesiapan menikah sendiri memerlukan adanya tanggung jawab dan menurut Stinett (1969) kompetensi untuk membantu pasangan dalam mencapai kemandirian perlu dipertimbangkan. Sedangkan Holman dan Li (1997) melihat pentingnya kesiapan dalam keuangan, pendidikan, usia, serta dukungan dari keluarga maupun teman akan calon pasangan (Badger, 2005). Menurut Pleck (2010) interaksi yang terjadi antara ayah dan anak yang telah memasuki masa emerging adult lebih banyak ke diskusi dan pemberian saran mengenai berbagai aspek kehidupan emerging adult (misalkan mengani pendidikan, karir, dan cinta) dan mengenai pandangan hidupnya (Princeton University, 2008). Pada masa emerging adult, fungsi kontrol ayah berkurang, tetapi ayah tetap terlibat dalam usaha anaknya dalam memutuskan sesuatu. Misalnya mengenai jurusan, pekerjaan/karir, atau pernikahan (Princeton University, 2008). Dalam dimensi warmth and responsiveness terdapat proses pengembangan kedekatan emosional dengan anak. Ayah menunjukkan afeksi yang hangat, seperti memeluk, mengatakan bahwa ayahnya menyangi si anak, dan mengapresiasi apa yang dilakukan anaknya. Ayah juga merespon kebutuhan dan perkataan anaknya, mendengarkan ungkapan perasaan anaknya, serta memperhatikan anaknya. Dimensi ini berkaitan dengan dimensi kematangan emosi dan kesehatan emosional kesiapan menikah yang dikemukakan oleh Blood (1978). Dimana invidu memiliki kemampuan untuk dapat siaga terhadap diri sendiri dan kemampuan mengidentifikasikan perasaan sendiri serta dapat mengatasi persoalan emosional yang dimiliki manusia seperti kecemasan, ketidaknyamanan, curiga, dan lain sebagainya.

Pernyataan-pernyataan di atas sejalan dengan hasil penelitian sebelumnya yang mendukung. Menurut Whitehead \& Popenoe (2000), emerging adult mendapatkan ide dan model pernikahan dari orangtua dan generasi sebelumnya (Badger, 2005). Larson (1988) dan Snyder dkk. (1997) mengemukakan bahwa orangtua cenderung memainkan peran pusat dalam membentuk pandangan anaknya yang dewasa mengenai pernikahan, begitu pula dengan persepsi akan kesiapan personal untuk menikah (Badger, 2005). Penelitian Axinn dan Thornton (1992) serta Heaton (2002) membuktikan bahwa sikap orangtua, perilaku, dan nilai yang dianut secara signifikan memberi dampak pada sikap dan kepercayaan emerging adult tentang pernikahan (Badger, 2005). Dari dua pernyataan di atas, keterlibatan ayah dalam pegasuhan memiliki hubungan dengan persepsi kesiapan menikah terutama pada dimensi kesiapan model peran. 


\section{S I M P U L A N}

Berdasarkan hasil penelitian didapatkan kesimpulan bahwa terdapat hubungan positif pada Kesiapan Menikah dengan Persepsi Keterlibatan Ayah dalam Pengasuhan. Dimensi warmth and responsiveness pada Persepsi Keterlibatan Ayah dalam Pengasuhan berkaitan dengan dimensi Kematangan Emosi dan Kesehatan Emosional Kesiapan Menikah yang dikemukakan oleh Blood (1978). Berbagai penelitian yang dilakukan sebelumnya membuktikan bahwa dimensi kesiapan model peran pada Kesiapan Menikah berkaitan dengan Keterlibatan Ayah dalam Pengasuhan.

Berdasarkan hasil penelitian yang dilakukan dan hasil analisa data, terdapat beberapa saran untuk emerging adult dan ayahnya. Emerging adult perlu meningkatkan interaksinya dengan ayah, sehingga keterlibatan ayah dapat meingkat, baik secara kuantitas maupun kualitas. Diharapkan dari interaksi ini ayah memiliki porsi keterlibatan yang lebih besar yang nantinya dapat berpengaruh pada kesiapan menikah emerging adult. Sedangkan bagi ayah, perlu meningkatkan keterlibatanya terkait dengan fungsi instrumentalnya, yaitu memberikan nasihat maupun membuka ruang diskusi dengan anak terkait pertimbangannya mengenai pilihan hidupnya maupun mengenai pernikahan. Selain itu ayah perlu memberikan contoh bagaimana ia berperan dalam keluarganya, sehingga anak dapat meningkatkan kesiapan perannya.

Selama pelaksanaan penelitian, penulis mendapati beberapa hambatan. Dari hambatan tersebut penulis memberikan beberapa saran yang perlu dipertimbangkan untuk penelitian selanjutnya:

a. Penelitian ini menggunakan alat ukur yang masing-masing skala memiliki aitem sebanyak 43 dan 44 aitem. Penggunaan aitem yang lebih sederhana dan ringkas perlu dipertimbangkan untuk menghindari ambiguitas dan kebingungan subjek dalam pengisian kuisioner.

b. Penelitian ini tidak membahas korelasi kedua variabel jika ditinjau dari: (1) usia, (2) lama pacaran, (3) status pekerjaan, (4) status hubungan: pacaran/tunangan, (5) status ayah: kandung/tiri maupun orangtua tunggal/bukan, (6) orientasi seksual subjek. Perlu dipertimbangan untuk membahas aspek-aspek demografis di penelitian selanjutnya untuk memperkaya kajian psikologi dalam persepsi keterlibatan ayah dalam pengasuhan dan kesiapan menikah.

\section{U C A P A N T ERIMA KA S I H}

Ucapan terima kasih penulis haturkan kepada Fakultas Psikologi Universitas Airlangga dan Sekretariat Himpunan Psikologi Wilayah Jawa Timur sebagai wadah penulis menimba ilmu dan mengembangkan diri sehingga artikel ilmiah ini bisa dipublikasikan.

\section{DEKLARASI POTENSI TERJADINYAKONFLIK KEPENTINGAN}

Ester Feliciana dan Duta Nurdibyanandaru tidak bekerja, menjadi konsultan, memiliki saham, atau menerima dana dari perusahaan atau organisasi manapun yang mungkin akan mengambil untung dari diterbitkannya naskah ini.

\section{PUST AKA ACUAN}

Abdullah, S. M. (2009, Februari). Keterlibatan Ayah dalam Pengasuhan Anak (Paternal Involvement) : Sebuah Tinjauan Teoritis. Jurnal Universitas Mercu Buana Yogyakarta, 1-20. Diakses dari http://fpsi.mercubuana-yogya.ac.id/wp-content/uploads/2012/06/Februari_2009_SriMuliati-A.pdf 
Arnett, J. J. (2000). Emerging adulthood: A theory of development from the late teens through the twenties. American psychologist, 469.

Arnett, J. J. (2004). Emerging Adulthod: The Winding Road form the Late Teens Through the Twenties (Vol. 2). New York, United States of America: Oxford University Press. Diakses dari http://jeffreyarnett.com/articles/EAB00K2004ch1.pdf

Azwar, S. (2012). Metode Penelitian. Yogyakarta: Pustaka Belajar.

Badan Pusat Statistik. (2018). Badan Pusat Statistik (BPS - Statistics Indonesia). Diakses dari Persentase Penduduk Berumur 10 Tahun ke Atas menurut Provinsi, Jenis Kelamin, dan Status Perkawinan, 2009-2017: https://www.bps.go.id/statictable/2012/04/19/1602/persentase-pendudukberumur-10-tahun-ke-atas-menurut-provinsi-jenis-kelamin-dan-status-perkawinan-20092017.html

Badan Pusat Statistika. (2010). Penduduk Berumur 10 Tahun Keatas Menurut Kelompok Umur dan Status Perkawinan - Kota Surabaya. Diakses dari Penduduk Berumur 10 Tahun Keatas Menurut Kelompok Umur dan Status Perkawinan - Kota Surabaya.: http://sp2010.bps.go.id/index.php/site/tabel?tid=271\&wid=3578000000\&lang=id

Badger, S. (2005). Ready or Not? Perceptions of Marriage Readiness among Emering Adults. Utah: Brimingham Young University.

Blakemore, J. 0., \& dkk. (2005). I Can't Wait to Get Married: Gender Differences in Drive to Marry. Sex Roles, 53, 327-335.

Blood, M., \& Bob. (1978). Marriage 3rd ed. New York: Free Press.

Brooks, J. (2010). The Proces of Parenting 8th Revised edition. United States: McGraw-Hill Education.

Dickson. (2015). 10 Kota Terbesar di Indonesia Menurut Jumlah Penduduknya. Diakses dari Ilmu Pengetahuan Umum: https://ilmupengetahuanumum.com/10-kota-terbesar-di-indonesiamenurut-jumlah-penduduknya/

Hodgins, B. D. (2007). Father Involvement in Parenting Young Children: A Content Analysis of Parent Education Programs in BC. Journal of Master of Education in Departement of Curriculum and Instruction University of Victoria.

Holman, T. B., \& Li, B. D. (1997, March 2). Premarital Factors Influencing Perceived Readiness for Marriage. Journal of Family Issues, 18, 124-144.

Nugent, P. M. (2013). Readiness. Diakses dari Psychology Dictionary: https://psychologydictionary.org/readiness/

Pleck, J. H. (2010). Paternal involvement: Revised conceptualization and theoretical linkages with child outcomes. In M. E. Lamb, \& M. E. Lamb (Ed.), The Role of the Father in Child Development (5th ed., pp. 67-107). London: John Wiley \& Sons Inc.

Princeton University. (2008). Resident Father Involvement and Outcomes in Emerging Adulthood. Diakses dari Princeton University: http://paa2008.princeton.edu/papers/80017

Ralston, N. C., \& Thomas, G. P. (2012). Developmental Task of Early Adulhood. In N. C. Ralston, \& G. P. Thomas, Improving COllege and University Teachig (pp. 21-22). London: Routledge. 
Rumondor, P. C. (2015). Kesiapan Menikah vs Persiapan Pernikahan. Diakses dari Faculty of Humanities, Psychology, Binus University: https://psychology.binus.ac.id/2015/06/23/kesiapan-menikahvs-persiapan-pernikahan/

Santrock, J. W. (2010). Life-Span Development Thirteenth Edition. New York: McGraw-Hill. 